\title{
$\mathrm{Na}_{2} \mathrm{O}-\mathrm{B}_{2} \mathrm{O}_{3}$ 系ガラス融液中における種々のイオン電極 反応のポテンシャルスイープ法による研究
}

\author{
高 橋 克 明 三 浦 嘉 也 \\ (岡山大学 工学部 工業化学科)
}

\begin{abstract}
$28.7 \mathrm{Na}_{2} \mathrm{O} \cdot 71.3 \mathrm{~B}_{2} \mathrm{O}_{3}$ 融液における $\mathrm{Cd}, \mathrm{Zn}, \mathrm{Tl}$ など単一原子価イオン及び $\mathrm{Fe}, \mathrm{Mn}, \mathrm{As}$ など レドックスイオンの白金電極に打ける還元反応を三角波掃引ポテシシシャルスイープ法で調ベた. 単 一原子価イオンはほとんどの場合金属状態まで可逆的に還元された。レドックスイオンは高価数の イオン状態から段階的に還元を受けることが分った. $\mathrm{Sn}^{4+} / \mathrm{Sn}^{2+}$ 系では吸着による前置ピークが観 察された. 電極反応が可逆なものについては半波電位を求め, $950^{\circ} \sim 790^{\circ} \mathrm{C}$ の温度範囲で電気化学 列を作成した. Kühl らの結果との比較では, $\mathrm{Cr}, \mathrm{Mn}$ 及び $\mathrm{Ce}$ イオンの間で酸化力はともに $\mathrm{Cr}^{6+}$ $/ \mathrm{Cr}^{3+}>\mathrm{Mn}^{3+} / \mathrm{Mn}^{2+}>\mathrm{Ce}^{4+} / \mathrm{Ce}^{3+}$ の順であったが，As と $\mathrm{Sb}$ イオンの順位には逆転が見られた. 電気化学列では, 酸化力は $\mathrm{Sb}^{5+} / \mathrm{Sb}^{3+}>\mathrm{As}^{5+} / \mathrm{As}^{3+}$ であり, これは Baak らのこれらの系の自由 エネルギーの密閉系における測定結果を支持した。電気化学列より算出した異なるレドックス対間 の反応の平衡定数のうち, $\mathrm{Cr}-\mathrm{Fe}, \mathrm{Mn}-\mathrm{As}$ 及び $\mathrm{Cr}-\mathrm{As}$ 系については, Paul らの分光学的手法に よる結果と反応の進行方向に一致が見られた. $\mathrm{Mn}-\mathrm{Ce}$ 系の平衡定数は大略一致した.
\end{abstract}

(1980 年 3 月 14 日受付)

\section{Voltammetric Analysis for Electrochemical Reactions of Various Ions in Molten Sodium Borate}

\author{
Katsuaki TAKAHASHI and Yoshinari MIURA \\ (Department of Industrial Chemistry, School of Engineering, Okayama University \\ 3-1-1, Tsushima, Okayama-shi 700
}

The cathodic reactions of simple ions such as $\mathrm{Cd}^{2+}, \mathrm{Ni}^{2+}$ and $\mathrm{Zn}^{2+}$ and redox ions such as $\mathrm{Fe}^{3+} / \mathrm{Fe}^{2+}, \mathrm{Cr}^{6+} / \mathrm{Cr}^{3+}$ and $\mathrm{As}^{5+} / \mathrm{As}^{3+}$ in molten sodium borate $\left(28.7 \mathrm{Na}_{2} \mathrm{O} \cdot 71.3 \mathrm{~B}_{2} \mathrm{O}_{3}\right)$ were investigated by potential sweep voltammetry with platinum electrodes. The electrolytic currents were measured when linearly changing potentials were applied to the electrodes. Potential sweep rates were selected between 10 and $0.02 \mathrm{~V} / \mathrm{s}$. The electrode reactions and reversible electrode potentials of various ions were determined by analysis of the peak potential and the peak current in the current-potential curve at $950^{\circ}, 900^{\circ}, 850^{\circ}$ and $790^{\circ} \mathrm{C}$.

Cadmium, zinc and nickel ions at lower temperature were reduced reversibly to metallic state with 2-electrons process without deposition on the electrode. On the other hand, lead and thallium ions were reduced reversibly to metallic state and deposited on the electrode. The latter results agree with the fact that these metals are preferentially adsorped on platinum electrode by Faradaic adsorption process in acidic aqueous solution.

Such redox ions as $\mathrm{Fe}^{3+} / \mathrm{Fe}^{2+}, \mathrm{Cu}^{2+} / \mathrm{Cu}^{+}, \mathrm{Sb}^{5+} / \mathrm{Sb}^{3+}$ and $\mathrm{As}^{5+} / \mathrm{As}^{3+}$ were reduced stepwisely. In the cases of former two ions, 1-electron steps were followed by the second reduction steps of 2-electrons or 1-electron, respectively, while in the cases of latter two ions 2-electrons steps were followed by the second 3-electrons steps. Chromium, cerium and manganese which are expected to be reduced stepwisely, showed only one reduction step, respectively, because the second step became obscure by disturbance of the large residual current of the base glass. The reduction of tin ions shows the first step caused by adsorption phenomenon and is followed by the second step caused by the reduction of $\mathrm{Sn}^{4+}$ to $\mathrm{Sn}^{2+}$. On many ions the results obtained by potential sweep method were almost compatible with the previous studies by chronopotentiometry ${ }^{1)}$. Potential sweep method was found to be more suitable 
than chronopotentiometry in terms of detailed study on the electrode reaction.

On the basis of these results, electrochemical series were established. For example, at $950^{\circ} \mathrm{C}$ the order of increase of oxidizing power was $\mathrm{Cr}^{6+} / \mathrm{Cr}^{3+}>\mathrm{Mn}^{3+} / \mathrm{Mn}^{2+} \simeq \mathrm{Sb}^{5+} / \mathrm{Sb}^{3+}>$ $\mathrm{Ce}^{4+} / \mathrm{Ce}^{3+}>\mathrm{Cu}^{2+} / \mathrm{Cu}^{+}>\mathrm{As}^{5+} / \mathrm{As}^{3+}>\mathrm{Sb}^{3+} / \mathrm{Sb}>\mathrm{Sn}^{4+} / \mathrm{Sn}^{2+}>\mathrm{Fe}^{3+} / \mathrm{Fe}^{2+}>\mathrm{Pb}^{2+} / \mathrm{Pb}^{2}>\mathrm{Cd}^{2+} / \mathrm{Cd}>$ $\mathrm{Tl}^{+} / \mathrm{Tl}>\mathrm{Zn}^{2+} / \mathrm{Zn}>\mathrm{Fe}^{2+} / \mathrm{Fe}$. The order of increase of oxidizing power among $\mathrm{Cr}, \mathrm{Mn}$ and Ce ions coincided with the result by Kühl et al. ${ }^{10)}$, but the order between $\mathrm{As}^{5+} / \mathrm{As}^{3+}$ and $\mathrm{Sb}^{5+} / \mathrm{Sb}^{3+}$ was reverse. The electrochemical series supports the results of measurement on the free energies of antimony and arsenic oxides in molten glass by Baak and Hornyak. ${ }^{12}$ )

Some equilibrium constants $K$ between different redox pairs were calculated from the electrochemical series. The $K$ value between iron and cerium ions approximately coincided with the value obtained by chemical analysis ${ }^{1}$. In comparison with the results on mutual interaction of different redox pairs obtained from optical absorption measurement and chemical analysis ${ }^{13)}$, the reactions were shown to proceed toward the same directions in the cases of chromium-iron, manganese-arsenic and chromium-arsenic. In the case of chromiumcerium, however, the reverse direction of reaction was obtained. On manganese-cerium the $K$ values obtained by these two different methods roughly agreed.

[Received March 14, 1980]

Key-words : Molten sodium borate, Electrochemical technique, Potential sweep method, Electrode reaction of metal ions, Electrochemical series, Redox equilibrium

\section{1. 緒言}

ガラス中に含まれるイオン間の酸化還元反応は，ガラ スの着色，コロイド生成，フォトクロミックガラスの増 感等の現象のみならず溶融・清澄などガラスの製造過程 に拉いても重要な因子である。 また, 班瑯及びセラミッ クコーティングにおいては，金属とガラス中に含まれる イオンとの酸化還元反応が婇薬の密着性に大きな影響を 及ぼす. 更に, ガラスの通電溶融における電極の消耗・ ガラスの污染も電極とガラス中のイオンとの酸化還元反 応としては握できる. 上記のようなイオン間又は 金属イオン間の反応を予測する最良の方法の一つは単一原子 価イオンについては金属/イオンの電極電位を, レドッ クスイオンについては高洒数イオン/低価数イオンの酸 化還元電位を測定し，得られる電位を大小の順に並べ た，いわゆる電気化学列を作ることである. 電気化学列 を利用することによって任意の 2 種のイオン間の反応の 進行方向が予測できるとともに反応の平衡定数を算出す ることが可能となる.

このような観点に立ち著者らは，前報1で電気化学的 手法の一つであるクロノポテンショメトリーを用いて $\mathrm{Na}_{2} \mathrm{O}-\mathrm{B}_{2} \mathrm{O}_{3}$ 系融液における $\mathrm{Ni}^{2+}, \mathrm{Co}^{2+}, \mathrm{Cd}^{2+}$ イオン等 の単一原子価イオン及び $\mathrm{Fe}^{3+} / \mathrm{Fe}^{2+}, \mathrm{Ce}^{4+} / \mathrm{Ce}^{3+}$ 等のレ ドックスイオンの電極反応を決定するとともに得られた 電気化学列及び異種のレドックス対閒の平衡定数につい て若干の考察を加えた. しかし, クロノポテンショメト リーでは S 字型の電位一時閒曲線を解析せねばならず, 半波電位がかなり負な物質では残余電流の影響を受けや 寸くなるため変曲点の決定が困難となる．それゆえ，電 極反応を決定できるイオン種は限定される。このような 場合, 電極反応の決定にはポテンシャルスイープ法が優 れていると考えられる. クロノポテンショメトリーでの
$\mathrm{S}$ 字型曲線は，この手法ではピークを持つ曲線となり， 解析は容易となる. 更に, 電位走查速度を広範囲に変化 させることが可能なため, 電極反応について, 更に詳し い知見を得ることができる.

本報ではガラスの組成を前報と同じく $28.7 \mathrm{Na}_{2} \mathrm{O}$. $71.3 \mathrm{~B}_{2} \mathrm{O}_{3}(\mathrm{~mol} \%)$ に固定し, 前報で測定対象としたイ オン種について再測定を試みるとともに, クロノポテン ショメトリーでは測定困難であったイオンについて, $790^{\circ} \sim 950^{\circ} \mathrm{C}$ の温度範囲で，三角波掃引ポテンシャルス イープ法で調べたものである. 種々の電位走查速度のも とで電流一電位関係の測定を行い，電極反応形式を決定 するとともに, 電極反応の可逆なものについては半波電 位を求め, 種々の温度に抢ける白金酸素電極基準の電気 化学列を決定した. 更に異種イオン間の平衡定数の算出 を行い, 従来得られた結果及び他の研究者の結果との比 較検討を試みた。

\section{2. ポテンシャルスイープ法の概略}

ポテンシャルスイープ法は, 電極電位を時間の関数と して変化させたとき, 電極間に流れる電流を測定する方 法である. 電位走査の仕方には種々あるが, 最も広く用 いられているのは，電位を時間に対して直線的に変化さ せる直線掃引 (linear sweep) 法であり, その理論的解 析は既に多くの研究者によって行わ机ている2 ${ }^{2,3)}$. 大過 剩の支持電解質を含む電解系に抒いて, 電極反応関与物 質 $\mathrm{Ox}, \operatorname{Red}$ が前報4) で詳しく述べた諸条件（(1) 溶液 は静止していること，(2) Ox 及び Red は半無限平面 拡散で移動すること）学満足している場合, 電位 $E_{\mathrm{i}}$ を $E$ を初期電位として，(1) 式のごとく直線的に負電位方 向に走查 (カソード走查) させると, $\mathrm{Ox}+n \mathrm{e} \rightleftharpoons \operatorname{Red}$ な る還元反応の進行に伴って，一般に注ある電位で電流が 
11 高橋克明 - 三浦嘉也

極大を示す電流一電位曲線が得られる.

$$
E=E_{\mathrm{i}}-v t
$$

ここで, $E_{\mathrm{i}}:$ 初期電位

$v$ : 電位走查速度（カソード走查で正，ア）

$$
\text { 一ド走查で負とする) }
$$

$t:$ 電解開始からの経過時間

この電流極大現象は定性的には次のように説明でき る. 電解の初期には Ox の電極表面濃度は，その沖合濃 度に等しい. 電位を負に走查していくと, ある電位から Ox の還元速度が増加し, 還元電流は増加していくこと になる. しかし，還元の進行に伴って，電極近傍の $\mathrm{Ox}$ は消費され，それは溶液沖合から拡散によって補給され ることになるが, 電位走查速度が大きな場合, 拡散の遅 れによって単位時間に電極表面に到達する $\mathrm{Ox}$ の量は徐 々に減少する. したがって, 電流は極大に達した後, 減 少していくことになる. ピーク電流から定量を, またピ 一ク電位から定性を行うことができる.

ピークの大きさ，ピークの位置及びその $v$ への依存 性は, 電極での還元反応 $\mathrm{Ox}+n \mathrm{e} \rightleftharpoons \operatorname{Red}$ の形式に依存 している. 以下にそれらの特徽的関係のみを記述する ${ }^{3)}$.

\section{$2.1 \mathrm{Ox}, \operatorname{Red}$ がともに可溶性（soluble）物質で電 極反応が可逆*1の場合}

ピーク電流 $i_{\mathrm{p}}$ 及びピーク電圧 $E_{\mathrm{p}}$ はそれぞれ (2),

(3) 式で与えられる.

$$
\begin{aligned}
& i_{\mathrm{p}}=0.447 n F A C^{\mathrm{O}} D_{\mathrm{O}}{ }^{1 / 2}\left(\frac{n F}{R T} v\right)^{1 / 2} \\
& E_{\mathrm{p}}=E_{1 / 2}-1.11 \frac{R T}{n F} \\
& E_{1 / 2}=E^{\mathrm{O}}+\frac{R T}{n F} \ln \frac{f_{\mathrm{O}} D_{\mathrm{R}}^{1 / 2}}{f_{\mathrm{R}} D_{\mathrm{O}}^{1 / 2}}
\end{aligned}
$$

ここで, $A$ : 電極表面積, $C^{\mathrm{O}}: \mathrm{Ox}$ の沖合濃度, $D_{\mathrm{O}}$, $D_{\mathrm{R}}$ : それぞれ $\mathrm{Ox}, \operatorname{Red}$ の拡散係数, $R$ : 気体定数, $T$ : 絶対温度, $E_{1 / 2}$ : 半波電位 $(\mathrm{Ox}+n \mathrm{e} \rightleftharpoons \operatorname{Red}$ に固有な 特異電位 $), E^{\mathrm{O}}: \mathrm{Ox}+n \mathrm{e} \rightleftharpoons \operatorname{Red}$ の標準電位, $f_{\mathrm{O}}, f_{\mathrm{R}}$ : それぞれ Ox, Red の活量係数

またピーク電流 $i_{\mathrm{p}}$ の半分の值 $i_{\mathrm{p}} / 2$ を与える電位 $E_{\mathrm{p} / 2}$ と $E_{\mathrm{p}}$ の間には (5), (6) 式の関倸がある.

$$
\begin{aligned}
& E_{\mathrm{p} / 2}=E_{1 / 2}+1.09 \frac{R T}{n F} \\
& \Delta E=E_{\mathrm{p} / 2}-E_{\mathrm{p}}=2.20 \frac{R T}{n F}
\end{aligned}
$$

\subsection{Ox, Red はともに可溶性物質であるが電極反応} が非可逆の場合*2

$i_{\mathrm{p}}, E_{\mathrm{p}}, \Delta E$ はそれぞれ (7)〜 (9) 式で表される.

$$
i_{\mathrm{p}}=0.496 n F A C^{\mathrm{O}} D_{\mathrm{O}^{1 / 2}}\left(\frac{\alpha n F}{R T} v\right)^{1 / 2}
$$

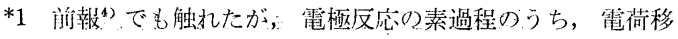
行反忘の速度が大きい系であること意味し，抎散過程が 電極反応の律速段階上なっている場合である.

*2 電極反忘の素過程のうち電荷移行反応が物質移動過程に 比へ遅く, 律速段階となっている系を意味する.
窵業協会誌 89 [3] 1981109

$$
\begin{aligned}
& E_{\mathrm{p}}=\frac{R T}{\alpha n F}\left(-0.78+\ln \frac{K_{f}{ }^{\mathrm{o}} f_{\mathrm{O}}}{D_{\mathrm{O}}{ }^{1 / 2}}-\frac{1}{2} \ln \frac{\alpha n F}{R T} v\right) \\
& \Delta E=E_{\mathrm{p} / 2}-E_{\mathrm{p}}=1.85 \frac{R T}{\alpha n F}
\end{aligned}
$$

電極反応の可逆性・非可逆性は電位走查速度 $v$ によ って異なる場合があり，ひが大きい場合に非可逆であっ たものが，vを小さくすると可逆系になる場合が多い。 寺た，可逆・非可逆は電極反応の速度と抬散による物質 の補給, 逸散の速さの相対関係によって決まる要素でも あるため, 温度によって変化する可能性も西る。

\section{3 電解生成物 Red が電極上に活量 1 で可逆的に析} 出する場合

$i_{\mathrm{p}}, E_{\mathrm{p}}$ はそれぞれ (10)，(11) 式で与えられる.

$$
\begin{aligned}
& i_{\mathrm{p}}=0.609 n F A C^{\mathrm{O}} D_{\mathrm{O}^{1 / 2}}\left(\frac{n F}{R T} v\right)^{1 / 2} \\
& E_{\mathrm{p}}=E^{\mathrm{O}}+\frac{R T}{n F} \ln f_{\mathrm{O}} C^{\mathrm{O}}-0.854 \frac{R T}{n F}
\end{aligned}
$$

また，

$$
\begin{aligned}
& E_{\mathrm{p} / 2}=E^{\mathrm{O}}+\frac{R T}{n F} \ln f_{\mathrm{O}} C^{\mathrm{O}}-0.0815 \frac{R T}{n F} \\
& \Delta E=E_{\mathrm{p} / 2}-E_{\mathrm{p}}=0.7725 \frac{R T}{n F}
\end{aligned}
$$

\section{4 電極反応関与物質が電極に吸着される場合}

電極反応関与物質が電極に吸着されると, 電極表面濃 度は沖合濃度よりも高くなるため, 電解電流の増加をも たらす。また，吸着の相互作用エネルギーが関与するた め, “挔散によるピーク電位と異なった電位でピークが生 ビることも起こり得る。この問題は Wopschall ららによ って, 定量的に取り扱われている。次のような吸着過程 を含む還元反応を考える.

$$
\begin{aligned}
& (\mathrm{Ox})_{\mathrm{sol}} \rightleftharpoons(\mathrm{Ox})_{\mathrm{ads}} \\
& \mathrm{Ox}+n \mathrm{e} \rightleftharpoons \mathrm{Red} \\
& (\mathrm{Red})_{\mathrm{sol}} \rightleftharpoons(\mathrm{Red})_{\mathrm{ads}}
\end{aligned}
$$

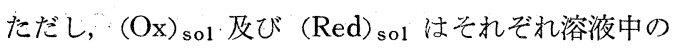
$\mathrm{Ox}, \operatorname{Red} を,(\mathrm{Ox})_{\mathrm{ads}}$ 及び $(\mathrm{Red})_{\mathrm{ads}}$ はそれぞれ電極 に吸着した $\mathrm{Ox}, \operatorname{Red}$ を示す.

Ox の強い吸着がある場合, Ox は吸着によって安定 化されるので $\mathrm{Ox}$ の拡散に基づく還元ピークよりむ負電 位に吸着によるピークが現れる.この場合, ピーク電流 はvに比例する．また $\mathrm{Ox}$ が弱く吸着している場合に は, 昖散に基づく還元ピークと分離したピークとしては 観察されないが，ピーク電流は大きくなり $i_{\mathrm{p}}$ は $v^{1 / 2} に$ 対して比例関倸を示さなくなる。一方， Red の強い吸 着があると Red が吸着により安定化するため, Ox が より還元を受けやすくなり, 通常の拡散ピークより正電 位側にピークが現れる。おた Red の弱い吸着の場合は, $\mathrm{Ox}$ のそれと同様の現象を示す。

さて, 最初カソー我走查 $E=E_{\mathrm{i}}-v t$ を行い, 時間 $t$ が $t=\lambda$ の時点で走査を折り返し, 正側へ向から走查(ケ 
ノード走查) $E=E_{\mathrm{i}}-2 v \lambda+v t$ を行った場合も，還元ピ 一クに対応したアノードピークが現れる，それぞれのピ 一ク電位及びピーク電流の間には種々の定量関係が存在 する. しかし，アノードピークは折り返し電位 $E_{2}$ の影 響を受けやすく, 正確な定量関係は $E_{\lambda}$ が十分負電位側 にある場合に限られる ${ }^{2}$. 本研究で用いた $\mathrm{Na}_{2} \mathrm{O}-\mathrm{B}_{2} \mathrm{O}_{3}$ 系ガラス融液では, 後述するように残余電流はかなり大 きく， $E_{\lambda}$ を大きくすることはガラスの電気分解を促進 するなど不都合が生じる，そこで，本実験では還元ピー クが得られたならば，すぐに電位走査を逆転させた，そ れゆえ，アノード走査によるピークは定量関係には利用 できず, 可逆・非可逆の補助的判定材料としてのみ利用 するにとどめた.

\section{3，実験}

\section{1 試料の調製}

溶媒として用いる基礎ガラスの組成は前報1),4) と同じ く, 28.7 Na2 $\mathrm{O} \cdot 71.3 \mathrm{~B}_{2} \mathrm{O}_{3}$ (mol\%) に固定した. その理 由は前回のクロノポテンショメトリーによる結果と今回 のポテンシャルスイープ法での結果との比較検討が可能 であることとクロノポテンショメトリーでの結果を更 に，発展に継続できる可能性があると配虑したことによ る. 電極反応物質としては, 前回測定対象としたもの $\left(\mathrm{CdCO}_{3}, \mathrm{NiO}, \mathrm{PbO}, \mathrm{CeO}_{2}, \mathrm{Fe}_{2} \mathrm{O}_{3}, \mathrm{Cr}_{2} \mathrm{O}_{3}, \mathrm{CuO}\right.$ 及び $\mathrm{SnO}_{2}$ ) 以外に $\mathrm{ZnO}, \mathrm{Tl}_{2} \mathrm{O}, \mathrm{Sb}_{2} \mathrm{O}_{3}, \mathrm{As}_{2} \mathrm{O}_{3}$ 及び $\mathrm{MnO}_{2}$ を選んだ．濃度はイオン種によって異なるが，0.4〜1.6 $\mathrm{mol} \%$ の範囲で適宜選定した. また, $\mathrm{Fe}, \mathrm{Cr}, \mathrm{As}$ などレ ドックスイオンについてはレドックス平衡を達成させる ため, $950^{\circ} \mathrm{C}$ に約 12 時間保持したものを測定に供した.

\section{2 実験方法}

電解槽及び電極系は前報4) と同様であり，電解槽は白 金るつぼ，溶融ガラス及び 3 本の白金電極で構成されて いる. 作用電極及び参照電極には $0.4 \mathrm{~mm} \phi$ の白金線を 用い，補助電極には白金板を用いた.

ファンクションジェネレーター（北斗電工製 HB 107 $\mathrm{A}$ 型) で発生させた $10 \sim 0.02 \mathrm{~V} / \mathrm{s}$ の範囲の電位走查速 度の単一三角波をポテンショスタット（北斗電工製 $\mathrm{HA}$ 101 型）に加え，作用電極の電位を規制する. その際の 作用電極と補助電極の間を流れる電解電流と白金参照電 極基準の電位の関係を, 電位走查速度が $1 \mathrm{~V} / \mathrm{s}$ 以下の場 合は，X-Y レコーダー（理研電子製 F-42 CP）によっ て，また電位走查速度が $2 \mathrm{~V} / \mathrm{s}$ 以上の場合には， $\mathrm{X}-\mathrm{Y}$ オシロスコープ（松下電子工業製 VP $542 \mathrm{~A}$ ）によって 記録した. 測定は $950^{\circ}, 900^{\circ}, 850^{\circ}, 790^{\circ} \mathrm{C}$ の 4 点で行 った.

\section{4. 実 験 結 果}

\section{1 支持電解質 $28.7 \mathrm{Na}_{2} \mathrm{O} \cdot 71.3 \mathrm{~B}_{2} \mathrm{O}_{3}$ の電流-電位}

\section{曲線}

まず, 溶媒として用いた $28.7 \mathrm{Na}_{2} \mathrm{O} \cdot 71.3 \mathrm{~B}_{2} \mathrm{O}_{3}$ につい てポテンシャルスイープ法による電流-電位関係を 調べ てみた. 図 1 は，950年 で得られたカソード走查の電流 一電位曲線である（カソード電流を負，アノード電流を 正で表示する. 以下の図においても同様). カソード走 查の初期においては，残余電流は 余り大きくなく，1 $\mathrm{mA} / \mathrm{cm}^{2}$ 以内の值であるが， 約 $-0.7 \mathrm{~V}$ より負になる と急激に大きくなり始め, 例えば $1 \mathrm{~V} / \mathrm{s}$ の電位走査速度 の場合, $-1.0 \mathrm{~V}$ で $15 \mathrm{~mA} / \mathrm{cm}^{2},-1.2 \mathrm{~V}$ では $60 \mathrm{~mA} /$ $\mathrm{cm}^{2}$ となり, 支持電解質の分解, この場合は前報)で述 べたように $\mathrm{Na}^{+}$イオンの還元析出反応が急速に起こり 始めることを示している. 一方, $-1.0 \mathrm{~V}$ で走查を折り 返した復路に抢いては， $-0.8 \sim-0.9 \mathrm{~V}$ 付近に電解生 成物の酸化によるブロードなアノードピークが観察され る.

この支持電解質に微量の金属イオンを加えた場合金属 イオンの還元によるピークが比較的アノード電位寄りに 観察される場合には，支持電解質の残余電流が小さい領 域に相当するので，明りょうなピークとなることが期待 できる. しかし金属イオンの還元が約 $-0.7 \mathrm{~V}$ より負 な領域で起こる場合には残余電流の影響が無視できなく なり，ピークは不明りょうとなる場合が多かった。 この ような場合には，相応する電位走查速度での残余電流の 值を考虑に入れ，電解電流を補正することも適宜試 み た.

4.2 クロノポテンショメトリーで測定対象としたイ オン種の電極反応及び両手法の比較

この項では前報1)のクロノポテンショメトリーで測定 対象としたイオンについて，ポテンシャルスイープ法で

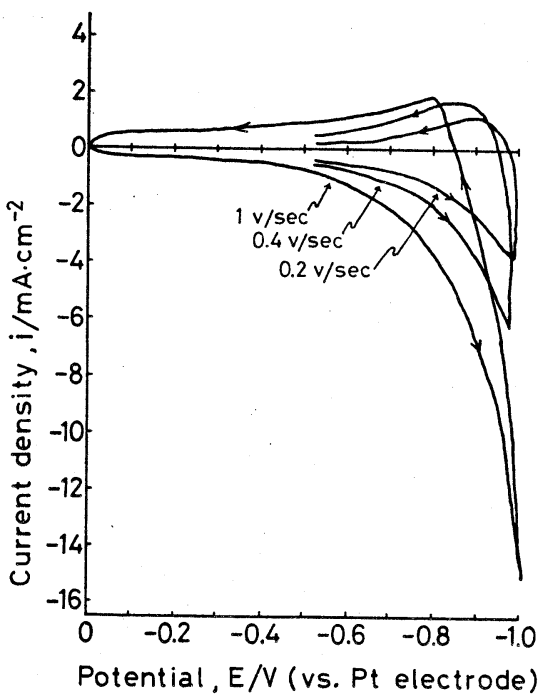

Fig. 1. Cathodic current-potential curves of supporting electrolyte, $28.7 \mathrm{Na}_{2} \mathrm{O} \cdot 71.3 \mathrm{~B}_{2} \mathrm{O}_{3}$ at various potential sweep rates at $950^{\circ} \mathrm{C}$. 
も測定を行い更に詳しい考察を加えるとともに, 両手法 で得られた電極反応機構について比較検討した結果を述 ベる.

\subsection{1. カドミウム}

$28.7 \mathrm{Na}_{2} \mathrm{O} \cdot 71.3 \mathrm{~B}_{2} \mathrm{O}_{3}$ ガラスに $\mathrm{CdCO}_{3}$ を $0.504 \mathrm{~mol} \%$ 加えた場合の $850^{\circ} \mathrm{C}$ に㧍ける電流一電位曲線を図 2 に示 す. $-0.82 \mathrm{~V}$ 付近に明りょうな電流ピークをもつ電流電位曲線が得られる．ピーク電位 $E_{\mathrm{p}}$ は電位走査速度に よってほとんど変化しない，このことは 2.1 節から明ら かなように， $\mathrm{Cd}^{2+}$ イオンの電極反応が可逆であること を示している. また, $-1.0 \mathrm{~V}$ で走査を折り返し, アノ 一ド走查を行った場合にも， $-0.65 \mathrm{~V}$ 付近に電解生成 物の再酸化による明りょうなピークが現れており, 可逆 系であることを裹付ける. 表 1 亿，各温度に抢ける $E_{\mathrm{p}}$, 半ピーク電位 $E_{\mathrm{p} / 2}, E_{\mathrm{p} / 2}-E_{\mathrm{p}}$ 及び (6), (13) 式より算

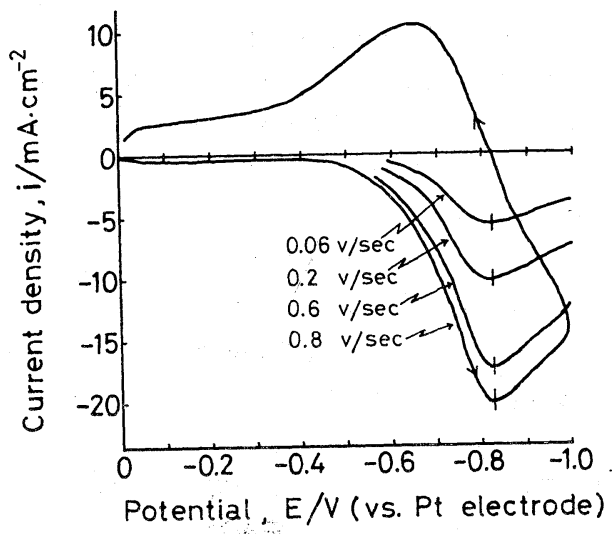

Fig. 2. Cathodic current-potential curves for $\mathrm{Cd}^{2+}$ ions in $28.7 \mathrm{Na}_{2} \mathrm{O} \cdot 71.3 \mathrm{~B}_{2} \mathrm{O}_{3}$ at various potential sweep rates at $850^{\circ} \mathrm{C}$. Concentration of $\mathrm{Cd}^{2+}$ ions : $0.504 \mathrm{~mol} \%$

Table 1. Cathodic peak potential $E_{\mathrm{p}}$, half-peak potential $E_{\mathrm{p} / 2}$ and number of electrons involved in the electrode process $n$ calculated from Eqs. (6) and (13) for $\mathrm{Cd}^{2+}$ ions in $28.7 \mathrm{Na}_{2} \mathrm{O} \cdot 71.3 \mathrm{~B}_{2} \mathrm{O}_{3}$ at various potential sweep rates $v$.

\begin{tabular}{|c|c|c|c|c|c|c|}
\hline temperature & $\begin{array}{l}\text { sweep rate, } \\
v(\mathrm{~V} / \mathrm{sec})\end{array}$ & $\begin{array}{l}E_{p} \\
(V)\end{array}$ & $\begin{array}{c}E_{p / 2} \\
(\mathrm{~V})\end{array}$ & ${ }_{(\mathrm{V})}^{E^{2} \mathrm{2}^{-E_{p}}}$ & $\begin{array}{l}n \text { value } \\
\text { from eq. (6) }\end{array}$ & $\begin{array}{l}n \text { value } \\
\text { from eq. (13) }\end{array}$ \\
\hline \multirow[t]{5}{*}{$950^{\circ} \mathrm{C}$} & 1 & -0.817 & -0.666 & 0.151 & 1.54 & 0.54 \\
\hline & 0.4 & -0.805 & -0.673 & 0.132 & 1.76 & 0.62 \\
\hline & 0.1 & -0.793 & -0.668 & 0.125 & 1.85 & 0.65 \\
\hline & 0.06 & -0.793 & -0.668 & 0.125 & 1.85 & 0.65 \\
\hline & 0.02 & -0.793 & -0.668 & 0.125 & 1.85 & 0.65 \\
\hline \multirow[t]{5}{*}{900} & 1 & -0.829 & -0.687 & 0.142 & 1.57 & 0.55 \\
\hline & 0.4 & -0.816 & -0.693 & 0.123 & 1.81 & 0.63 \\
\hline & 0.1 & -0.810 & -0.691 & 0.119 & 1.87 & 0.66 \\
\hline & 0.06 & -0.807 & -0.699 & 0.108 & 2.06 & 0.72 \\
\hline & 0.02 & -0.807 & -0.697 & 0.110 & 2.02 & 0.71 \\
\hline \multirow[t]{5}{*}{850} & 1 & -0.825 & -0.699 & 0.126 & 1.69 & 0.59 \\
\hline & 0.4 & -0.820 & -0.708 & 0.112 & 1.90 & 0.67 \\
\hline & 0.1 & -0.822 & -0.707 & 0.115 & 1.85 & 0.65 \\
\hline & 0.06 & -0.822 & -0.706 & 0.116 & 1.84 & 0.64 \\
\hline & 0.02 & -0.820 & -0.705 & 0.115 & 1.85 & 0.65 \\
\hline
\end{tabular}

出した電荷移行数 $n$ の值を示す. $950^{\circ}$ 及び $900^{\circ} \mathrm{C} て ゙$ は, vが大きい領域で, $E_{\mathrm{p}}$ はvの増加とともに負に移 行しており, 幾分非可逆的因子が混入していることを示 すが， $0.1 \mathrm{~V} / \mathrm{s}$ よりも遅い領域では， $E_{\mathrm{p}}$ は $v$ 亿依存せ ずほぼ一定となり, 可逆系となる. 一方, 電極反応関与 物質がともに可溶であるとの仮定で得られた (6) 式から 算出した $n$ の值は, いずれの温度でも 1.5 2.05 の值が 得られ，特に $v$ が遅い場合にはほぼ整数としての 2 と 見なし得る 1.85〜2.05 が得られた. しかし, 電解生成 物が可逆的に電極に析出する場合の理論式 (13) では, $n$ は 0.5 0.7 の值となり, 反応式を割り当てることは 困難である. 以上の結果より, $\mathrm{Cd}^{2+}$ イオンは, $\mathrm{Cd}^{2+}+$ $2 \mathrm{e} \underset{\text { (reversible) }}{\rightleftarrows} \mathrm{Cd}$ (soluble) なる 2 電子還元電極反応を行 うものと思われる， $\mathrm{Cd}^{2+}$ イオンは金属状態まで還元さ れるが，白金電極上には析出しない，これはクロノポテ ンジョメトリーによる結果 ${ }^{4) * 3}$ とも一致している.

可逆領域での $E_{\mathrm{p}}$ から，(3) 式を用いて算出した半波 電位 $E_{1 / 2}$ は， $950^{\circ}, 900^{\circ}, 850^{\circ}$ 及び $790^{\circ} \mathrm{C}$ で，それぞ れ $-0.730,-0.745,-0.760$ 及び $-0.764 \mathrm{~V}$ であっ た. なお半波電位を, 電流がピーク電流の半分のときの 電位 $E_{\mathrm{p} / 2}$ を用いる（5）式より算出した場合む，(3) 式 より算出した值と誤差内で一致するとの結果を得た. そ れゆえ， $E_{\mathrm{p}}$ の決定が困難な電流一電位曲線に対しては， (5) 式より半波電位を算出しても差し支えないと考えら れる.

一方，クロノポテンショメトリーで得られた四分波電 位 $E_{\tau / 4}$ （ポテンシャルスイープ法での半波電位と理論的

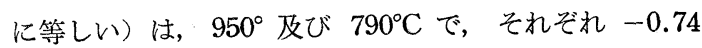
及び $-0.76 \mathrm{~V}$ であり ${ }^{1), 4)}$ ，ポテンシャルスイープ法の 相応する温度での值とほとんど等しく, 両手法には互換 性があることが分った. また, ピーク電流密度の電位走 査速度の平方根に対するプロットは，(2) 式から 予想されるように, 良好な直線性を示した. この ことは, $\mathrm{Cd}^{2+}$ イオンの電極への拡散過程が全電極 反応の律速段階であることを意味している.

\subsection{2 銅}

銅イオンを $0.943 \mathrm{~mol} \%$ 含むガラスについて得 られた電流-電位曲線の一例を図 3 に示寸. 2 段 階の還元波が得られ， $-0.2 \mathrm{~V}$ から $-0.35 \mathrm{~V}$ に かけてのプラトー気味な段波は $-0.6 \mathrm{~V}$ 付近で のピークヘとつながっていく. 初段波は電位走查 速度が大きい場合でもピークとはならないので解

*3 可溶 (soluble), という蒠葉は, 本来, 電極反応生 成物もイオン状態であり溶液に溶解するか, 又は金 属状態まで還元されても例えば，水銀電極を用いた 場合のようにアマルガムを作り水銀中に溶解するこ とを意味する. 固体電極を用いた本実験で, 2.1 節 の取り扱いが可能であることは, 生成した金属カド ミウムが金属霧 $\left.{ }^{4}\right)$ 又はコロイドとしてガラス融液中 に溶解しているものと考えられる. 


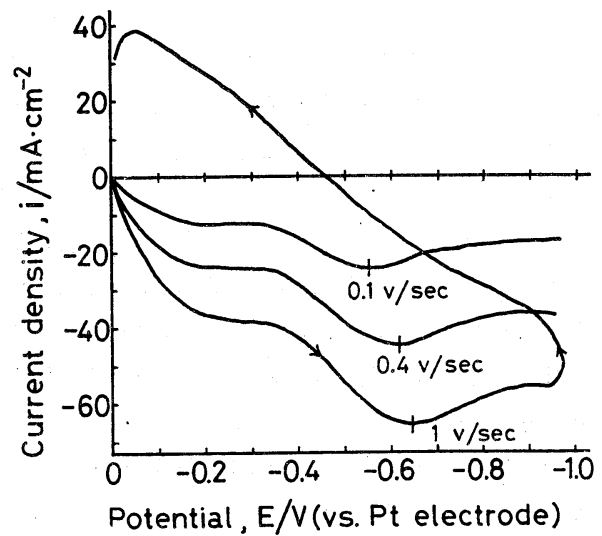

Fig. 3. Cathodic current-potential curves for copper ions in $28.7 \mathrm{Na}_{2} \mathrm{O} \cdot 71.3 \mathrm{~B}_{2} \mathrm{O}_{3}$ at $950^{\circ} \mathrm{C}$. Concentration of copper ions : $0.943 \mathrm{~mol} \%$

析に困難を伴うがプラトーの中点をピーク電位とみなし 解析を行った場合，可逆性が見いだされるとともに，(6) 式から $n$ として 1.04 1.12 程度のほぼ 1 とみなせる 值が得られた。

一方， 2 段目のピークは図 3 から明らかなように, 電 位走査速度が遅くなるにしたがって正電位側に移る。 ま た走查を折り返した場合には，プラトーに対応するピー クのみが現れて抢り， 2 段目の還元ピークに相当するア ノードピークは観察されていないので，この反応は非可 逆系である.

次に，反応をより明確にするために定電位電解を試み た. 図 3 において，プラトーを示す電位のほぼ中間の電
位， $-0.3 \mathrm{~V}$ 及び大略ピーク電位に相当する $-0.62 \mathrm{~V}$ にそれぞれ電位を保持し，いずれの場合にも約 $1 \mathrm{C}$ の 電気量を通電した場合 ${ }^{* 4},-0.3 \mathrm{~V}$ 保持では, 白金電極 表面は通電前後で何ら変化が認められなかった. しかし $-0.62 \mathrm{~V}$ 保持では, 通電後の白金電極表面は金属光沢 を失っておう，析出物の存在が認められた．原子吸光分 析の結果, 析出物は銅と確認された.

この定電位電解の結果を援用すれば，銅イオンの電流 一電位曲線の最初のプラトーは $\mathrm{Cu}^{2+}$ イオンの $\mathrm{Cu}^{+}$への 還元反応, $\mathrm{Cu}^{2+}+\mathrm{e} \underset{\text { (reversible) }}{\rightleftarrows} \mathrm{Cu}^{+}$を割り付けることが妥 当である. 一方，ホウ酸塩ガラス中では銅イオンの不均

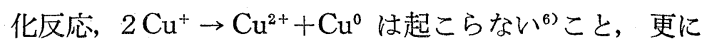
$\mathrm{Cu}^{2+}$ 及び $\mathrm{Cu}^{+}$イオンの還元反応の内, $\mathrm{Cu}^{2+}+\mathrm{e} \rightleftharpoons \mathrm{Cu}^{+}$ の電極電位が一番正電位であることを考虑に入れ，反応 の自由エネルギー変化 $(\Delta F)$ と電極電位 $(E)$ の相関関 係 $(\Delta F=-n F E)$ を利用した簡単な計算を行うことに より, $\mathrm{Cu}^{2+}+\mathrm{e} \rightarrow \mathrm{Cu}^{+}, \mathrm{Cu}^{2+}+2 \mathrm{e} \rightarrow \mathrm{Cu}, \mathrm{Cu}^{+}+\mathrm{e} \rightarrow \mathrm{Cu}$ の順で電極電位はより負な值になるとの結果が得られ る. 図 3 に扔けるプラトーより負な電位では $\mathrm{Cu}^{2+}$ イオ ンは $\mathrm{Cu}^{2+}+\mathrm{e} \rightarrow \mathrm{Cu}^{+}$反応で消費されてしまっているの で第 2 ピークは $\mathrm{Cu}^{2+}$ イオンの $\mathrm{Cu}$ へ還元反応ではな

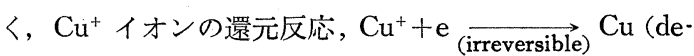
posit）に相当しているものと考えられる.

\subsection{3 ス ズ}

スズイオンを $0.436 \mathrm{~mol} \%$ 含むガラスの $790^{\circ} \mathrm{C}$ にお ける電流-電位曲線の一例を図 4 に示す. 図(a) は $1 \mathrm{~V} / \mathrm{s}$ で電位走查を行ったものである. $-0.3 \mathrm{~V}$ 付近にブロー (a) Sn ions at $790^{\circ} \mathrm{C}$

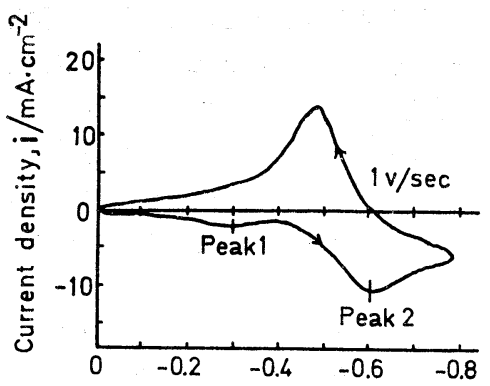

Potential, E/V (vs. Pt electrode) (b) Peak 1 at $-0.3 \mathrm{~V}$

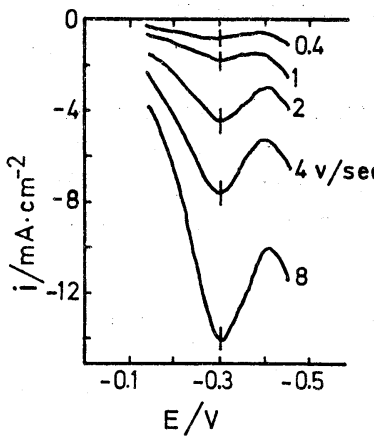

Fig. 4. Cathodic current-potential curves for tin ions in 28.7 $\mathrm{Na}_{2} \mathrm{O} \cdot 71.3 \mathrm{~B}_{2} \mathrm{O}_{3}$ at $790^{\circ} \mathrm{C}$. Concentration of tin ions : $0.436 \mathrm{~mol} \%$ (a) : Current-potential curve at $1 \mathrm{~V} / \mathrm{s}$

(b) : Peak 1 at $-0.3 \mathrm{~V}$

(c) : Peak 2 at $-0.6 \mathrm{~V}$
(c).Peak 2 at $-0.6 \mathrm{~V}$

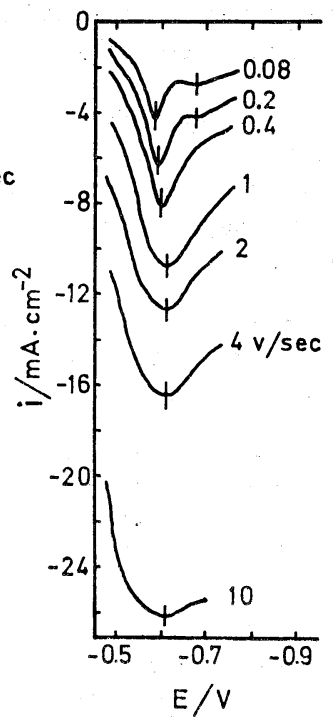

*4 ファラデーの法則が $100 \%$ の効率で成立するとした場合 $1 \mathrm{C}$ の通電により 1 電子反忘及び 2 䉓子反応でそれぞれ $0.66 \mathrm{mg}$ 及 び $0.33 \mathrm{mg}$ の金属銅が析出すると試算できる. 電極表面積が $0.165 \mathrm{~cm}^{2}$ の場合，それぞれ約 5 及び $2.5 \mu \mathrm{m}$ の厚さで白金電極 上に析出したことになる. 
ドな還元ピーク（ピーク 1 と呼ぶ）が観察されるととも に, $-0.6 \mathrm{~V}$ 付近に明りょうな第 2 ピーク（ピーク 2 と 呼ぶ）が現れる. ピーク 1 は図 (b) に拡大して示すよ うに，そのピーク電位は $v$ に依存せず一定值を示すが， ピーク電流值は $v$ にって大きく変化している. ピー ク電流密度のv及び $\sqrt{v}$ に対するプロットを試みた ところ， $\sqrt{v}$ に対しては曲線となったが，vに対して はかなりよい直線性を示した.このことはこのピークが 2.4 節で述べたように, 吸着過程を含む電極反応に詨応 していることを示している.しかも，主ピークよりも正 電位側に位置しているため, 電解生成物の強い吸着によ るピークであることが分る. また，この吸着現象は温度 が上昇するほど減少した。

一方, $-0.6 \mathrm{~V}$ 付近のピーク 2 については, (c) に拡 大して示すように，10 から $0.4 \mathrm{~V} / \mathrm{s}$ までの電位走查速 度では波形はほぼ相似したものとなり，またその $E_{\mathrm{p}}$ は $v$ に無関係に一定であり，可逆な系で女ることを示す結 果が得られた. (6) 式より得られる $n$ の值はこの電位 走查速度範囲では 2 とみなし得る $1.8 \sim 2.1$ の間の值が 得られた. これは $\mathrm{Sn}^{4+}$ の可逆的 2 電子還元によるピー クと思われる. しかしながら, vが $0.4 \mathrm{~V} / \mathrm{s}$ 以下では, このピークは正電位側に移っていくとともにピークの形 状がより急峻になり，更に $-0.67 \mathrm{~V}$ 付近に新たにブロ 一ドなピークが現れ始める.この現象は以下に述べるよ うに, 速い電位走查速度では電極反応速度が遅いためほ とんど追従できなかった異なった電極反応が，走査速度 の低速度化に従って顕在化し, 電流值に寄与してくるた めと説明することができる.ピークの形状の急峻化から 電荷移行数が大きい電極反応, $\mathrm{Sn}^{4+} \rightarrow \mathrm{Sn}$ が想定され, $\mathrm{Sn}^{4+} \rightarrow \mathrm{Sn}^{2+}$ と競合しているものと考えられる. また， 低速度電位走查で現れる $-0.67 \mathrm{~V}$ 付近のブロードなピ 一クは, $\mathrm{Sn}^{2+} \rightarrow \mathrm{Sn}$ なる非可逆電極反応によるものと思 われる. 以上の結果の内, 吸着現象に関してはクロノポ

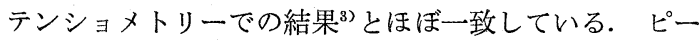
クに関してはポテンシャルスイープ法によってより詳し い考察が可能となった。

\subsection{4 ニッケル, 鉊, 鉄, クロム, セリウム}

上記のイオン種についてはクロノポテンショメトリー による結果との 互換性が認められる場合が多かったの で,ここでは結果の要約と主な相違点についてのみ記述 する.

$\mathrm{Ni}^{2+}$ イオンの白金電極上での還元反応は，ほぼ $850^{\circ} \mathrm{C}$ を境にして，それ以上では， $\mathrm{Ni}^{2+}+2 \mathrm{e} \underset{\text { (irreversible) }}{\stackrel{d \approx 0.6}{\longrightarrow}} \mathrm{Ni}$ (soluble), $850^{\circ} \mathrm{C}$ 以下では, $\mathrm{Ni}^{2+}+2 \underset{\text { (reversible) }}{\stackrel{2}{\rightleftarrows}} \mathrm{Ni}$ (soluble)・と決定された. この結果は大部分の点でクロノポ テンショメトリーによる結果と一致しているが，以前の 研究では $950^{\circ} \mathrm{C}$ でも電極反応は可逆であった. しかし 今回の $950^{\circ} \mathrm{C}$ での挙動は非可逆的因子が混入している.
可逆性は電荷移動過程と抎散など他の過程との相対的速 度に依存したものである7゙. それゆえ, 注目している電 極反応に固有な性質ではなく, 実験条件にようて異なる 場合が多いが， $\mathrm{Ni}^{2+}$ イインの場合，電極反応機構の詳 細な研究に対して, より適しているポテンシャルスイー プ法による結果の方が信頼できるものと考えられる.な お, 高温では非可逆であるが，低温になるほど可逆系に 移っているが, これはイオンの拡散係数の温度依存性が 電極反応速度のそれより大きいため, 高温では電荷移動 過程が律速段階になったとも考えられる.

鉛イオンの場合, $1 \sim 0.1 \mathrm{~V} / \mathrm{s}$ の範囲の比較的速い電位 走査速度では非可逆系の挙動を示し， $0.1 \mathrm{~V} / \mathrm{s}$ 以下の電 位走査速度では電極反応は可逆系へと移るとの結果を得 た. 可逆な領域で ${ }^{(6)}$ 式からは $n$ として $4.8 \sim 5.3$ と 5 に近い值が,一方，(13)式からは $1.7 \sim 1.9$ とほぼ 2 に近 い值が得られた. 鉛イオンに対し 5 電子反応は不自然な ので電解生成物が析出する反応式, $\mathrm{Pb}^{2+}+2 \mathrm{e} \underset{\text { (reversible) }}{\stackrel{(}{\rightleftarrows}}$ $\mathrm{Pb}$ (deposit) を割り当てるのが妥当であろう. 非可逆域 $(v>0.1 \mathrm{~V} / \mathrm{s})$ での電極反応としては, 可逆域での類推 から $\mathrm{Pb}$ の非可逆的析出反応, $\mathrm{Pb}^{2+}+2 \mathrm{e} \underset{\text { (irreversible) }}{\stackrel{\mathrm{Pb}}{ } \mathrm{Pb}}$ (deposit) を割り当てた. 鉛の析出反応に対する結果は, クロノポテンショメトリーの結果とほぼ一致している が，前報では低温域で可逆領域を見いだすことができな かった1). ポテンシャルスイープ法でそれが可能となっ たのは, 電位走査速度を広範に変化させることが可能な ためであろう.さて，他の金属に比べ鉛が析出しやすい のは, 水溶液系で $\mathrm{Pb}^{2+}$ イオンが $\mathrm{Pd}$ 及び $\mathrm{Pt}$ 電極に対 し著しい吸着能を示し，Faraday 吸着により $\mathrm{Pb}$ 金属被 膜として析出しやすいといら事実限と一致しており，白 金と析出した鈶との 親和力が大きいことを意味してい る.

鉄イオンは 2 段階の還元反応を示し，第 1 段還元反応 は $\mathrm{Fe}^{3+}+\mathrm{e} \underset{\text { (reversible) }}{\longrightarrow} \mathrm{Fe}^{2+}$ なる 可逆反応に 相当するこ と, 及び第 2 段階は初段波で生成した $\mathrm{Fe}^{2+}$ イオンが $\mathrm{Fe}$ まで還元される反応に相当することが分った.

クロムイオンの場合クロノポテンショメトリーでは不 明りょうながら 2 段階の波が観察されたが, ポテンシャ ルスイープ法では正電位に近い領域で一つの還元ピーク が現れた.しかし，スパン電圧を $1.8 \mathrm{~V}$ まで広げた場 合でも, 解析対象となるような明りょうな別のピークは 現れなかった.このピークは $\mathrm{Cr}^{6+}+3 \mathrm{e} \underset{\text { (reversible) }}{\stackrel{(}{\rightleftarrows}} \mathrm{Cr}^{3+}$ なる 3 電子可逆反応に対応しているとの結果を得た.

セリウムイオンの場合もかなり正電位に近い領城で一 つの還元ピークのみが観察され， $\mathrm{Ce}^{4+}+\mathrm{e} \underset{\text { (reversible) }}{\rightleftharpoons} \mathrm{Ce}^{3+}$ なる可逆 1 電子反応を割り当てることが可能であった. 鉄及びセリウムイオンの解析結果はクロノポテンショメ トリーの結果とほぼ一致した。 
なお，それぞれのイオンの半波電位の值は後述の表 3 に一括して示した.

\section{3 新たに測定対象としたイオンの電極反応}

この項では新たに測定を行った亜鉛，タリウム，アン チモン, ヒ素及びマンガンイオンの電流電位曲線の解 析結果について述べる。

\subsection{1 垔 鉊}

図 5 に $950^{\circ} \mathrm{C}$ での亜鉛イオン（濃度 : $0.804 \mathrm{~mol} \%$ ) の電流一電位曲線の一例を示す. $-1.0 \mathrm{~V}$ 付近にショル ダ一状の電流の停帯が観察される. これは母体ガラスの みの電流一電位曲線には現れないものであり，覀鉛イ才 ンの関与したものと見なせるが，かなり負電位領域での 反応であるため, 残余電流の影響を顕著に受けているも のと思われる. 各電位での残余電流の值を考慮に入れ， 亜鉛イオンのみの電解電流を求めると, ショルダ一は微 小ながらピークとなった. そのピーク電位は $v$ に無関 係であり, 反応は可逆系と見なせた. この関係は $950^{\circ} \mathrm{C}$ 以外の他の温度でも見いだされた. また，反応の電子数 は（6）式より， $n=1.9 \sim 2.1$ の值が得られた. それゆ

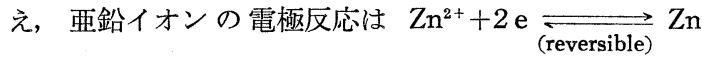
(soluble) と考えられる.

\subsection{2 タリウム}

図 6 に示す電流一電位曲線のようにタリウムイオン(濃 度 : $0.733 \mathrm{~mol} \%)$ の電極反応は $\mathrm{Zn}^{2+}$ イオンより更に負 電位領域 $(-1.1 \sim-1.2 \mathrm{~V})$ で起こるため $\mathrm{Zn}^{2+}$ イオン 同様, ショルダーになった. 残余電流を考慮に入れ，タ リウムイオンの真の電解電流を求め解析を行ったとこ ろ， $E_{\mathrm{p}}$ は表 2 に示すように，vが $0.1 \mathrm{~V} / \mathrm{s}$ 以下では走 查速度に無関係に一定值を示し，可逆系と見なせた。一 方， 反応の電子数 $n$ は表 2 に示すように，(6) 式の析 出物が 可逆の式では $n=2.4 \sim 2.7$ と不合理な值が得ら れるが，可逆析出の（13）式を用いると，vが $0.1 \mathrm{~V} / \mathrm{s}$ 以下ではほぼ 1 に近い值が得られた。 それゆえ, 電極反

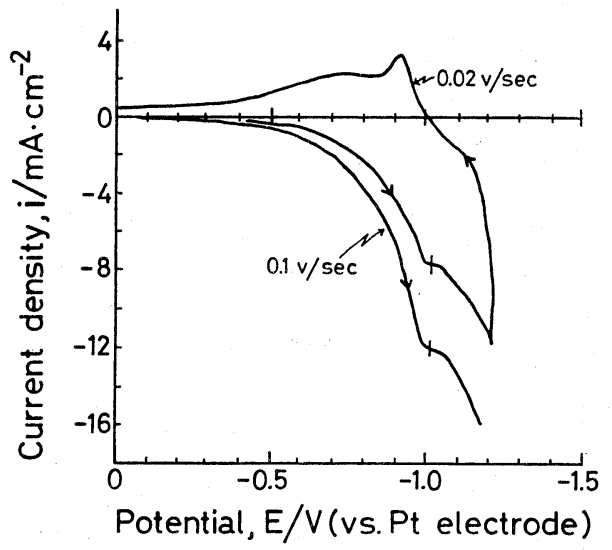

Fig. 5. Cathodic current-potential curves for $\mathrm{Zn}^{2+}$ ions in $28.7 \mathrm{Na}_{2} \mathrm{O} \cdot 71.3 \mathrm{~B}_{2} \mathrm{O}_{3}$ at $950^{\circ} \mathrm{C}$. Concentration of $\mathrm{Zn}^{2+}$ ions : $0.804 \mathrm{~mol} \%$
応として, $v>0.1 \mathrm{~V} / \mathrm{s}$ で $\mathrm{Tl}^{+}+\mathrm{e} \underset{\text { (irreversible) }}{\overrightarrow{\mathrm{T}}} \mathrm{Tl}$ (deposit), $v \leqq 0.1 \mathrm{~V} / \mathrm{s}$ のとき, $\mathrm{Tl}^{+}+\mathrm{e} \underset{\text { (reversible) }}{\stackrel{(\text { revo- }}{\rightleftarrows}} \mathrm{Tl}$ (depo. sit）を割り当てた。 Tl が白金電極上に他の金属より析 出しやすいのは鉛と同様, $\mathrm{Tl}$ が 水溶液系で $\mathrm{Pd}$ 及び $\mathrm{Pt}$ 電極に対し吸着能が大きく，被膜として析出しやす いという事実 ${ }^{8)}$ と一致している.

\subsection{3 アンチモン}

アンチモンはガラス中で $\mathrm{Sb}^{5+}$ 及び $\mathrm{Sb}^{8+}$ イオンとして 存在している.アンチモンイオン（濃度 : $0.750 \mathrm{~mol} \%$ ) に対して得られた電流一電位曲線には図 7 に示すように カソード及びアノード走査とも二つのピークが現れ， 2 段の反応が起こることを示している. $-0.2 \mathrm{~V}$ 付近の還 元ピークは電位走査速度が $0.4 \mathrm{~V} / \mathrm{s}$ 以下では可逆であり, (6) 式から得られる $n$ は $1.8 \sim 2.0$ であった. それゆ

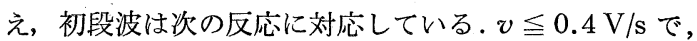

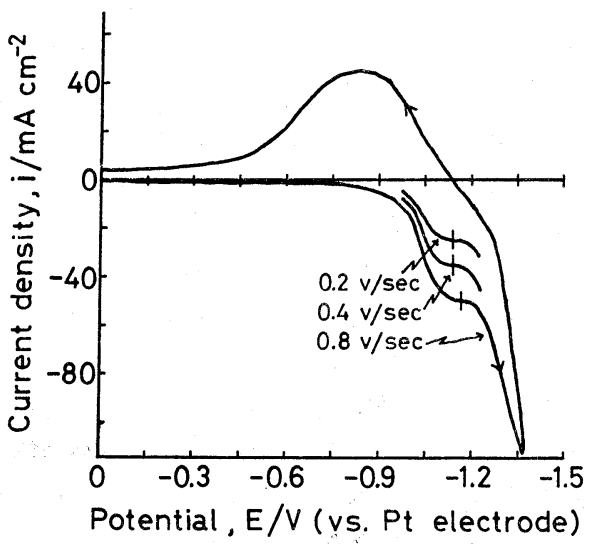

Fig. 6. Cathodic current-potential curves for $\mathrm{Tl}^{+}$ions in $28.7 \mathrm{Na}_{2} \mathrm{O} \cdot 71.3 \mathrm{~B}_{2} \mathrm{O}_{3}$ at $900^{\circ} \mathrm{C}$. Concentration of $\mathrm{Tl}^{+}$ions : $0.733 \mathrm{~mol} \%$

Table 2. Cathodic peak potential $E_{\mathrm{p}}$ and number of electrons involved in the electrode process $n$ calculated from Eqs. (6) and (13) for $\mathrm{Tl}^{+}$ions in $28.7 \mathrm{Na}_{2} \mathrm{O} \cdot 71.3 \mathrm{~B}_{2} \mathrm{O}_{3}$ at various potential sweep rates $v$.

\begin{tabular}{lllll}
\hline $\begin{array}{c}\text { temperature } \\
\left({ }^{\circ} \mathrm{C}\right)\end{array}$ & $\begin{array}{c}\text { sweep rate, } \\
(\mathrm{V} / \mathrm{sec})\end{array}$ & $\begin{array}{c}E_{p} \\
(\mathrm{~V})\end{array}$ & $\begin{array}{c}n \text { value } \\
\text { from eq. (6) }\end{array}$ & $\begin{array}{c}n \text { value } \\
\text { from eq. (13) }\end{array}$ \\
\hline 950 & 1 & 1.16 & 1.8 & 0.63 \\
& 0.4 & 1.13 & 2.3 & 0.82 \\
& 0.1 & 1.12 & 2.4 & 0.83 \\
& 0.06 & 1.11 & 2.7 & 0.95 \\
& 0.02 & 1.11 & 2.8 & 0.97 \\
900 & 1 & 1.17 & 1.6 & 0.55 \\
& 0.4 & 1.14 & 1.9 & 0.67 \\
& 0.1 & 1.11 & 2.3 & 0.80 \\
& 0.06 & 1.10 & 2.5 & 0.87 \\
& 0.02 & 1.10 & 2.5 & 0.87 \\
& 1 & 1.11 & 1.7 & 0.59 \\
& 0.4 & 1.11 & 1.7 & 0.59 \\
& 0.1 & 1.05 & 2.7 & 1.0 \\
& 0.06 & 1.05 & 2.7 & 1.0 \\
& 0.02 & 1.05 & 2.7 & 1.0 \\
\hline
\end{tabular}




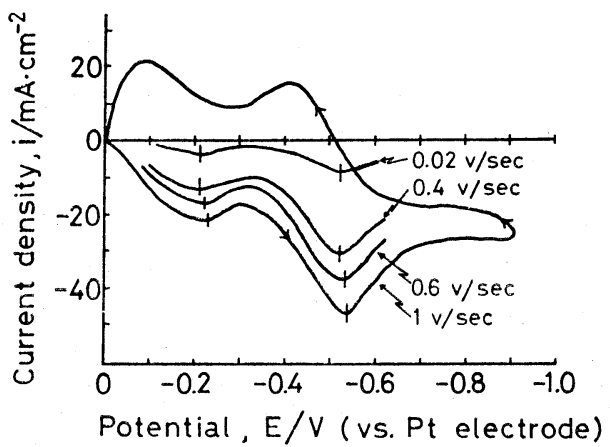

Fig. 1. Cathodic current-potential curves for antimony ions in $28.7 \mathrm{Na}_{2} \mathrm{O} \cdot 71.3 \mathrm{~B}_{2} \mathrm{O}_{3}$ at $790^{\circ} \mathrm{C}$. Concentration of antimony ions : $0.750 \mathrm{~mol} \%$

$\mathrm{Sb}^{5+}+2 \mathrm{e} \underset{\text { (reversible) }}{\rightleftarrows} \mathrm{Sb}^{3+},-0.52 \mathrm{~V}$ 付近の第 2 ピークも $v \leqq 0.4 \mathrm{~V} / \mathrm{s}$ では可逆であり, 同様の解析より $\boldsymbol{n}$ として 2.7〜2.9 が得られ，このピークは $\mathrm{Sb}^{3+}$ イオンの金属ま での還元反応, $\mathrm{Sb}^{8+}+3 \mathrm{e} \underset{\text { (reversible) }}{\rightleftarrows} \mathrm{Sb}$ (soluble) に対応 していると結論した．他の温度でも上記の 2 段反応が起 こることを確かめた.

\subsection{4 ヒ素}

ヒ素もアンチモンと同じくガラス中で $\mathrm{As}^{5+}$ 及び $\mathrm{As}^{3+}$ イオンとして存在する.しかし，得られた電流一電位曲 線は図 8 に示すように，アンチモンのそれとはかなり異 なっている. 還元方向の電位走査で $-0.5 \mathrm{~V}$ 付近にプ ラトーが現れ，次いで，第 1 段波にピークを持つ第 2 波 ヘとつながっていく.アアンチモンでは二つのピークは $0.3 \mathrm{~V}$ 程度分離していたため, 各々明りょうなピークと して分離できたが，七素の場合には $80 \mathrm{mV}$ 程度しか離 れておらず，そのため第 1 段波はピークとならず，つぶ れてプラトー状となるのであろう．プラトーの中点をピ 一ク電位とみなして波形解析を行ったところ， $n$ の值と して 1.9 2.1 が得られるとともに， $E_{\mathrm{p}}$ は $v$ に無関係 であり，可逆系とみなせた，それゆえ，初段波は次の反

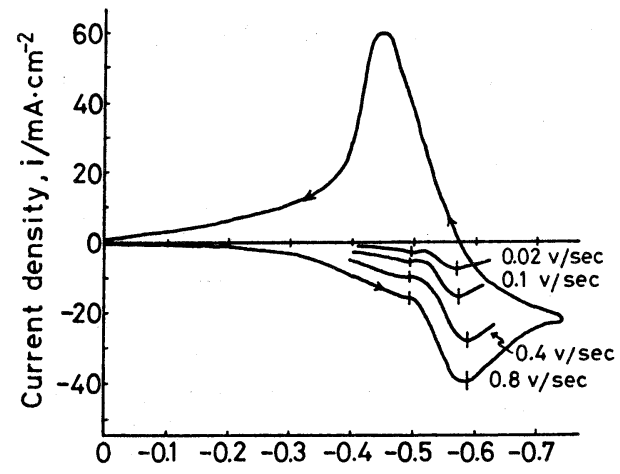

Potential, E/V (vs. Pt electrode)

Fig. 8. Cathodic current-potential curves for arsenic ions in $28.7 \mathrm{Na}_{2} \mathrm{O} \cdot 71.3 \mathrm{~B}_{2} \mathrm{O}_{3}$ at $900^{\circ} \mathrm{C}$. Concentration of arsenic ions : $1.00 \mathrm{~mol} \%$
応に対応しているものと思われる.

$$
\mathrm{As}^{5+}+2 \mathrm{e} \underset{\text { (reversible) }}{\rightleftharpoons} \mathrm{As}^{3+}
$$

なお，この反応の半波電位は，ピーク電位の決定にあい まいさがあるため, ピーク電流の半分のときの電位 $E_{\mathrm{p} / 2}$ を用いた（5）式により決定した. 結果は後述の表 3 に示 与.

一方, 第 2 ピークに関しては, その $E_{\mathrm{p}}$ は $v$ が小さ くなるにしたがって正方向に移り, 非可逆系の挙動とな るが, $0.1 \mathrm{~V} / \mathrm{s}$ より低速度の電位走査では $E_{\mathrm{p}}$ は一定值 となり，可逆系となった. また，第 2 波の可逆領域に対 して得られる $n$ の值は (6) 式では 4.8～5.1 の範囲の 值となったが，第 2 の反応に 5 電子反応を割り付けるこ とは不合理である. 一方，(13）式より得られる $n$ の值 は $1.7 \sim 1.8$ となり，予想される $\mathrm{As}^{3+}+3 \mathrm{e} \rightleftharpoons \mathrm{As}$ なる 3 電子反応よりかなり小さい. ヒ素は白金と合金を作り やすく，合金中のヒ素の活量は1よりかなり小さくなる ものと思われる. そのため, 電解生成物が活量 1 で析出 するとして得た（13）式から大きくずれるものと考えら れる.

\subsection{5 マン ガン}

マンガンイオンはガラス中では 2 価と 3 価の状態で共 存している. Paul ら ${ }^{9)}$ はアルカリホウ酸塩ガラス中での $\mathrm{Mn}^{2+}-\mathrm{Mn}^{3+}$ の平衡関係を調べている．彼らの結果を援 用すると $28.7 \mathrm{Na}_{2} \mathrm{O} \cdot 71.3 \mathrm{~B}_{2} \mathrm{O}_{3}$ における，例えば $900^{\circ} \mathrm{C}$ での $\mathrm{Mn}^{3+} / \mathrm{Mn}^{2+}$ 比は 0.16 となり, $\mathrm{Mn}^{2+}$ の比率が大 きい. $\mathrm{MnO}_{2}$ を $1.63 \mathrm{~mol} \%$ 含む $28.7 \mathrm{Na}_{2} \mathrm{O} \cdot 71.3 \mathrm{~B}_{2} \mathrm{O}_{3}$ ガラスを $950^{\circ} \mathrm{C}$ に約 12 時間保持し, レドックス平衡 を達成させた試料について，得られた電流一電位曲線の 一例を図 9 に示す. カソード走査の場合 $-0.15 \mathrm{~V}$ 付近 にブロードなピークが観察されるとともに，更に -0.85 $\mathrm{V}$ 付近に微弱ながらショルダ一状波形が現れており，マ

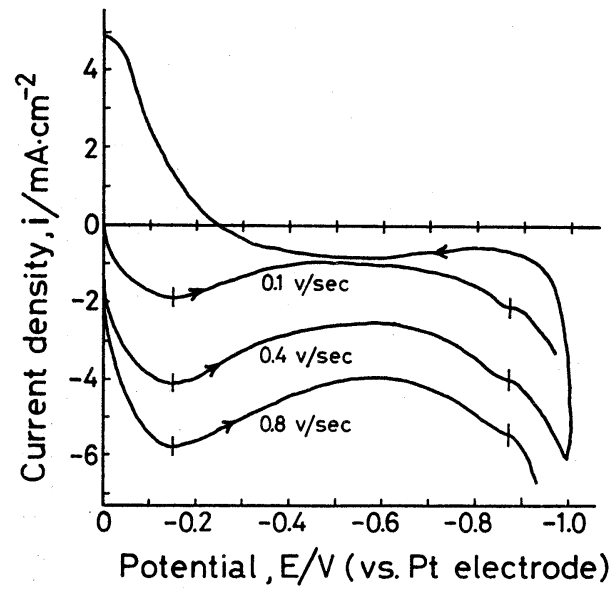

Fig. 9. Cathodic current-potential curves for manganese ions in $28.7 \mathrm{Na}_{2} \mathrm{O} \cdot 71.3 \mathrm{~B}_{2} \mathrm{O}_{3}$ at $850^{\circ} \mathrm{C}$. Concentration of manganese ions : 1.63 mol\% 
ンガンイオンが段階的に還元反忘を受けることを示唆し ている. いずれのピークも可逆的挙動を示しており，(6) 式から算出した第 2 ピークの電荷移行数はほぼ 2 であっ た. それゆえ第 2 ピークには $\mathrm{Mn}^{2+}$ イオンの可逆 2 電子 還元反応, $\mathrm{Mn}^{2+}+2 \mathrm{e} \rightleftharpoons \mathrm{Mn}$ (soluble) を割り当 (reversible)

てることができる，一方，第 1 ピークについて（6）式か ら算出した $n$ の値は $1.4 \sim 1.5$ となり，予想される 1 電 子反応とは一致しない. 第 1 ピークの形状は, 本来は例 えば図 2 の $\mathrm{Cd}^{2+}$ イオンの還元ピークのごとく, 徐々に 電流の増加を伴いながらピークに至る曲線となるはずで ある.しかし，ピークの位置が白金の電位（（0V) に近 いため，正電位側に現れるはずである裾野部分が測定不 能となり， $0 \mathrm{~V}$ ，で急激な立ち上がりとなり，曲線がひず む結果， $n$ の值が予想值とずれるものと考えられる.こ のことは前述の銅イオンの第 1 ピーク（図 3）にも当て はまる現象であろう．以上のことを考慮に入れると第 1 ピークには $\mathrm{Mn}^{3+}$ イオンの可逆 1 電子還元反応, $\mathrm{Mn}^{3+}$ te $\underset{\text { (reversible) }}{\rightleftharpoons} \mathrm{Mn}^{2+}$ を割り当てても差し支えないものと 考えられる.

\section{5. $28.7 \mathrm{Na}_{2} \mathrm{O} \cdot 71.3 \mathrm{~B}_{2} \mathrm{O}_{3}$ 融液中での電気化学列及び レドックス対間の平衡定数に関する考察}

単一原子価イオン及びレドゥクスイオンの $28.7 \mathrm{Na}_{2} \mathrm{O}$ . $71.3 \mathrm{~B}_{2} \mathrm{O}_{3}$ 融液中での電極反応のうち， 反応形式が明 確でしかも可逆なものについて，950 $, 900^{\circ}, 850^{\circ}$ 及び $790^{\circ} \mathrm{C}$ で算出された半波電位 $E_{1 / 2}$ を負の值の大きい順 に並べた，いわゆる電気化学列を表 3 に示す:ここで, 電極に析出する反店式を示するのについては (11) 式に おいて $f_{\mathrm{O}}=1, C^{\mathrm{O}}$ : イオンの沖合濃度，を代入して算出 した值である. 電極電位が負で大きな值ほど, 還元作用

Table 3. Half wave potentials $E_{1 / 2}$ of the reductions of various metal ions in $28.7 \mathrm{Na}_{2} \mathrm{O}$. $71.3 \mathrm{~B}_{2} \mathrm{O}_{3}$ at $950^{\circ}, 900^{\circ}, 850^{\circ}$ and $790^{\circ} \mathrm{C}$.

clectrode reaction half wave potential $E_{1 / 2}$ (V) (vs. Pt electrode)

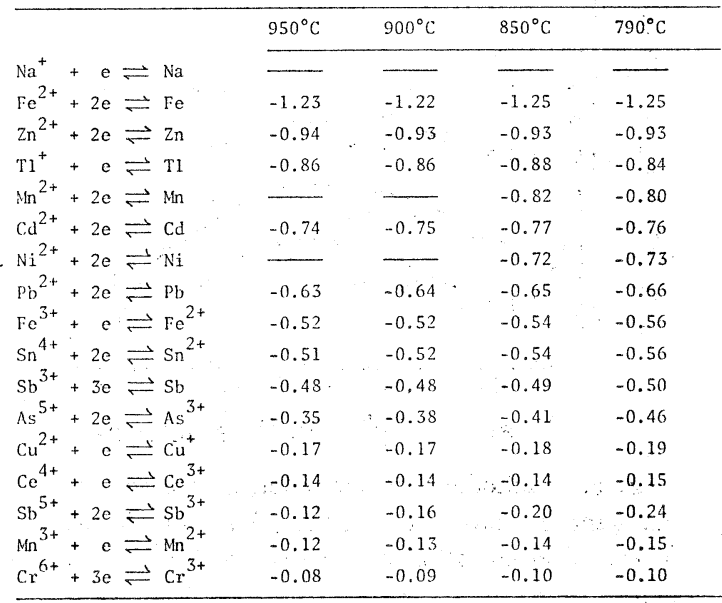

が大きいことを意味している． $\mathrm{Na}^{+}$イオンの還元反応は 溶媒としてのものであるため, その電位を正確に定める ことはできないが，最も後放電物質であるので最上段に 書いた. $950^{\circ} \mathrm{C}$ での電気化学列の順序は他の温度でもほ ぼ保たれているが， $\mathrm{Cu}^{2+} / \mathrm{Cu}^{+}$の電位が $850^{\circ}$ 及び $790^{\circ} \mathrm{C}$ では $\mathrm{Sb}^{5+} / \mathrm{Sb}^{3+}$ の電位より正側に移っている. 電極電位 は温度上昇にしたがって正電位側に移るものが多いが, 現状では参照電極として用いた白金電極の電位の温度依 存性が不明であるので，この傾向を説明することは困難 であり，また異なった温度で電位を比較することは意味 を持たない, なお，ク口ノポテンショメトリーで得られ た $790^{\circ} \mathrm{C}$ における電気化学列 ${ }^{1)}$ との比較においては，ほ とんどのイオンについて電極電位は $50 \mathrm{mV}$ の誤差内で 大略一致した。しかし, $\mathrm{Cu}^{2+} / \mathrm{Cu}^{+}$については今回の測 定值が $80 \mathrm{mV}$ 正電位の值となり, 不一致は大きいがポ テンシャルスイープ法による測定值の方がより信頼でき る值であると考えている.

さて，2種又はそれ以上のイオンが混在し，原子価変 化を起こす酸化還元平衡は着色ガラスの製造において重 要であるので従来よりよく研究されている. Kühl ら ${ }^{10)}$ は 2 種のレドックス対を含む急冷ガラスの分光学的研究 より，酸化物の酸化力の大小を表 4 (a) のごとく内部酸 素圧 (inner oxygen pressure) で表示した. 内部酸素圧 の大きな酸化物ほど，酸化力が大きいことを意味する。 一方，Tress ${ }^{11)}$ は純粋な 酸化物の標準自由エネルギー $\Delta G^{\circ}$ を用い; 比較的低温 で酸化物 の $\Delta G^{\circ}$ の温度変化 $\left(\Delta G^{\circ}=R T \ln p_{\mathrm{O}_{2}}\right.$, ここで $p_{\mathrm{O}_{2}}$ は酸化物の酸素解離圧) を求め，表 4(b) の結果を得ている. 表 4(a) 及び（b) において，マンガンを除けば順位は一致している、マン ガンの順位の不一致に対して Tress は $\mathrm{Mn}_{2} \mathrm{O}_{3}$ より高 位の酸化物 $\mathrm{Mn}_{2} \mathrm{O}_{7}$ の存在の可能性を示晙しているが, 常温での純粋な酸化物の $\Delta G^{\circ}$ を高温でのガラス系にも 適用している点，その結論には疑問が残る ${ }^{9)}$. 表 3 より， クロム，マンガン及びセリウムにおける酸化力の差異は

Table 4. Redox oxides in order of their oxidation potential. (a): From Kühl et al. ${ }^{10)}$, (b) : From Tress ${ }^{11)}$

(a)

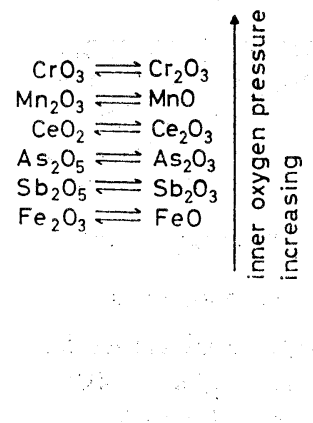

(b)

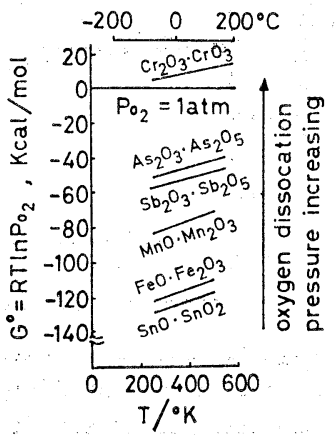


わずかであるが $\mathrm{Cr}^{6+}>\mathrm{Mn}^{3+}>\mathrm{Ce}^{4+}$ の順で小さくなっ ており，Kühl らの観察結果と一致している. さて，表 3 の電気化学列と表 4 との結果における不一致は七素と アンチモンの順位について見いだされる. 電気化学列で は $\mathrm{Sb}^{5+}$ は $\mathrm{As}^{5+}$ より酸化力が大きい。しかし, Kühl ら 及び Tress の結果ではいずれも $\mathrm{As}^{5+}$ の酸化力が $\mathrm{Sb}^{5+}$ より大きくなっている.この不一致の説明に対し, Baak らの結果 ${ }^{22)} 引$ 用してみる. Baak らはケイ酸塩ガラ ス中での $\mathrm{SbO}_{1.5}(\mathrm{gl})+1 / 2 \mathrm{O}_{2}(\mathrm{~g}) \rightleftharpoons \mathrm{SbO}_{2.5}(\mathrm{gl})$ 及び $\mathrm{AsO}_{1.5}(\mathrm{gl})+1 / 2 \mathrm{O}_{2}(\mathrm{~g}) \rightleftharpoons \mathrm{AsO}_{2.5}(\mathrm{gl})$ (ここで（gl) は ガラス中を意味する）の自由エネルギーを密閉系で実 測し， ヒ素の方がアンチモン系より 酸素解離圧一温度ダ イヤグラムの下方に位置する結果を得ている. その理由 として, 彼らは $\mathrm{As}_{2} \mathrm{O}_{3}$ の沸点 $\left(457^{\circ} \mathrm{C}\right)$ が $\mathrm{Sb}_{2} \mathrm{O}_{3}$ のそ れ $\left(1425^{\circ} \mathrm{C}\right)$ と比較して著しく低いため, Kühl らの開 放系での観察では $\mathrm{As}^{3+}$ の逸散により, $\mathrm{Sb}^{5+}+\mathrm{As}^{3+} \rightleftharpoons$ $\mathrm{Sb}^{3+}+\mathrm{As}^{5+}$ は見脚け上，左方に進むのであろうと説明 している. Tress のダイヤグラムとの相異は現時点では 不明であるが, 純物質とガラス中ではヒ素又はアンチモ ンは存在状態が変化している可能性も否定できない.

さて，標準電極電位がそれぞれ $E^{\mathrm{O}}{ }_{1}$ 及び $E^{\mathrm{O}}{ }_{2}$ である 2 種のレドックス対, $R_{1}{ }^{(m+n)+} / R_{1}{ }^{m+}$ 及び $R_{2}{ }^{(x+y)+} / R_{2}{ }^{x+}$ が共存している場合，平衡反応， $y R_{1}{ }^{(m+n)+}+n R_{2}{ }^{x+} \rightleftharpoons$ $y R_{1}{ }^{m+}+n R_{2}(x+y)+$ 平衡定数 $K$ は (17) 式で関係付け ることができる1).

$$
\ln K=\frac{n y F}{R T} \Delta E
$$

(ただし,$y=n$ のとき $\left.\ln K=\frac{n F}{R T} \Delta E\right)$

ここで, $F$ : ファラデー定数, $R$ : 気体定数, $T:$ 絶 対温度, $\Delta E=E^{\mathrm{O}_{1}}-E^{\mathrm{O}}{ }_{2}$

半波電位 $E_{1 / 2}$ は(4)式加ら明らかなように, $f_{\mathrm{O}} \approx f_{\mathrm{R}}$ 及び $D_{\mathrm{O}} \approx D_{\mathrm{R}}$ の場合, $E^{\mathrm{O}}$ にほぼ等しい. レドックス イオンの場合この条件が満足される可能性は大きく, $E_{1 / 2} \approx E^{\mathrm{O}}$ と仮定できると思われる. また, $\mathrm{Pb}^{2+}, \mathrm{Tl}^{+}$ のように還元析出するイオンにつトての表 3 の電極電位 は (11) 式から $E^{\mathrm{O}}$ を用いて算出した $E_{\mathrm{p}}$ そのもので あるので表 3 の電極電位を用いてガラス中における種々 の組み合わせのレドックス対間の平衡定数を算出するこ とができる. 表 5 に $950^{\circ}, 900^{\circ}, 850^{\circ}$ 及び $790^{\circ} \mathrm{C}$ での 平衡定数の計算結果の一例を示す. このうち $\mathrm{Ce}-\mathrm{Fe}$ 系 $790^{\circ} \mathrm{C}$ での值 93 は急冷試料の化学分析法で得られた 值 ${ }^{1)}$ ，86〜105 とよく一致していると言え， 平衡定数の 電気化学的決定法の有効性の一つの傍証となろう.

さて, Paul ら ${ }^{13)}$ はアルカリケイ酸塩, ホウ酸塩 2 成 分ガラス中で, $\mathrm{Cr}-\mathrm{Fe}, \mathrm{Mn}-\mathrm{As}, \mathrm{Cr}-\mathrm{As}, \mathrm{Mn}-\mathrm{Ce}$ 等 2 種 のレドックス対を反応させた場合の平衡関係を調べてい る. 化学分析及び 比色分析により 各イオンの 濃度を求 め, レドックス対の組み合わせによっては平衡定数を算
Table 5. Some examples of equilibrium constants $K$ in mutual interactions of different redox pairs in molten $28.7 \mathrm{Na}_{2} \mathrm{O} \cdot 71.3 \mathrm{~B}_{2} \mathrm{O}_{3}$ at $950^{\circ}$, $900^{\circ}, 850^{\circ}$ and $790^{\circ} \mathrm{C}$.

\begin{tabular}{|c|c|c|c|c|}
\hline \multirow[b]{2}{*}{ reaction } & \multicolumn{4}{|c|}{ equilibrium constant, $K$} \\
\hline & $950^{\circ} \mathrm{C}$ & $900^{\circ} \mathrm{C}$ & $850^{\circ} \mathrm{C}$ & $790^{\circ} \mathrm{C}$ \\
\hline $2 \mathrm{Ce}^{4+}+\mathrm{Sb}^{3+} \rightleftharpoons 2 \mathrm{Ce}^{3+}+\mathrm{Sb}^{5+}$ & 0.62 & 1.3 & 2.9 & 7.8 \\
\hline $\mathrm{Sn}^{4+}+2 \mathrm{Fe}^{2+} \rightleftharpoons \mathrm{Sn}^{2+}+2 \mathrm{Fe}^{3+}$ & 1.0 & 0.92 & 0.94 & 1.0 \\
\hline $\mathrm{Mn}^{3+}+\mathrm{Ce}^{3+} \rightleftharpoons \mathrm{Mn}^{2+}+\mathrm{Ce}^{4+}$ & 1.3 & 1.2 & 1.1 & 1.0 \\
\hline $\mathrm{Sb}^{5+}+2 \mathrm{Cu}^{+} \rightleftharpoons \mathrm{Sb}^{3+}+2 \mathrm{Cu}^{2+}$ & 2.8 & 1.5 & 0.73 & 0.32 \\
\hline $\mathrm{Cr}^{6+}+3 \mathrm{Ce}^{3+} \rightleftharpoons \mathrm{Cr}^{3+}+3 \mathrm{Ce}^{4+}$ & 4.9 & 4.3 & 4.3 & 4.0 \\
\hline $2 \mathrm{Cr}^{6+}+3 \mathrm{Sb}^{3+} \rightleftharpoons 2 \mathrm{Cr}^{3+}+3 \mathrm{Sb}^{5+}$ & 5.8 & 42 & $9.5 \times 10^{2}$ & $7.4 \times 10^{3}$ \\
\hline $\mathrm{As}^{5+}+\mathrm{Sn}^{2+} \rightleftharpoons \mathrm{As}^{3+}+\mathrm{Sn}^{4+}$ & 24 & 17 & 17 & 9.5 \\
\hline $\mathrm{Cu}^{2+}+\mathrm{Fe}^{2+} \rightleftharpoons \mathrm{Cu}^{+}+\mathrm{Fe}^{3+}$ & 26 & 31 & 41 & 59 \\
\hline $2 \mathrm{Cu}^{2+}+\mathrm{As}^{3+} \rightleftharpoons 2 \mathrm{Cu}^{+}+\mathrm{As}^{5+}$ & 28 & 61 & $1.0 \times 10^{2}$ & $3.6 \times 10^{2}$ \\
\hline $\mathrm{As}^{5+}+2 \mathrm{Fe}^{2+} \rightleftharpoons \mathrm{As}^{3+}+2 \mathrm{Fe}^{3+}$ & 34 & 15 & 16 & 9.7 \\
\hline $\mathrm{Ce}^{4+}+\mathrm{Fe}^{2+} \rightleftharpoons \mathrm{Ce}^{3+}+\mathrm{Fe}^{3+}$ & 35 & 43 & 60 & 93 \\
\hline $2 \mathrm{Ce}^{4+}+\mathrm{As}^{3+} \rightleftharpoons 2 \mathrm{Ce}^{3+}+\mathrm{As}^{5+}$ & 49 & $1.2 \times 10^{2}$ & $2.2 \times 10^{2}$ & $8.9 \times 10^{2}$ \\
\hline $2 \mathrm{Mn}^{3+}+\mathrm{As}^{3+} \rightleftharpoons 2 \mathrm{Mn}^{2+}+\mathrm{As}^{5+}$ & 77 & $1.6 \times 10^{2}$ & $2.5 \times 10^{2}$ & $8.9 \times 10^{2}$ \\
\hline $\mathrm{Sb}^{5+}+\mathrm{As}^{3+} \rightleftharpoons \mathrm{Sb}^{3+}+\mathrm{As}^{5+}$ & 79 & 89 & 75 & $1.1 \times 10^{2}$ \\
\hline $2 \mathrm{Cu}^{2+}+\mathrm{Sn}^{2+} \rightleftharpoons 2 \mathrm{Cu}^{+}+\mathrm{Sn}^{4+}$ & $6.6 \times 10^{2}$ & $1.0 \times 10^{3}$ & $1.8 \times 10^{3}$ & $3.4 \times 10^{3}$ \\
\hline $\mathrm{Sb}^{5+}+\mathrm{Sn}^{2+} \rightleftharpoons \mathrm{Sb}^{3+}+\mathrm{Sn}^{4+}$ & $1.9 \times 10^{3}$ & $1.5 \times 10^{3}$ & $1.3 \times 10^{3}$ & $1.1 \times 10^{3}$ \\
\hline $\mathrm{Sb}^{3+}+2 \mathrm{Fe}^{2+} \rightleftharpoons \mathrm{Sb}^{3+}+2 \mathrm{Fe}^{3+}$ & $2.0 \times 10^{3}$ & $1.4 \times 10^{3}$ & $1.2 \times 10^{3}$ & $1.1 \times 10^{3}$ \\
\hline $\mathrm{Cr}^{6+}+3 \mathrm{Fe}^{2+} \rightleftharpoons \mathrm{Cr}^{3+}+3 \mathrm{Fe}^{3+}$ & $2.1 \times 10^{5}$ & $3.3 \times 10^{5}$ & $9.2 \times 10^{5}$ & $3.2 \times 10^{6}$ \\
\hline $2 \mathrm{Cr}^{6+}+3 \mathrm{As}^{3+} \rightleftharpoons 2 \mathrm{Cr}^{3+}+3 \mathrm{As}^{5+}$ & $2.8 \times 10^{6}$ & $3.0 \times 10^{7}$ & $2.0 \times 10^{8}$ & $1.1 \times 10^{10}$ \\
\hline $2 \mathrm{Cr}^{\mathrm{O}^{+}}+3 \mathrm{Sn}^{2+} \rightleftharpoons 2 \mathrm{Cr}^{3+}+3 \mathrm{Sn}^{4+}$ & $3.8 \times 10^{10}$ & $1.3 \times 10^{11}$ & $1.0 \times 10^{12}$ & $9.4 \times 10^{12}$ \\
\hline
\end{tabular}

出している. 以下に表 5 の該当する組み合わせとの比較 検討を試みる.

(1) $\mathrm{Cr}-\mathrm{Fe}$ 系: Paul らは $3 \mathrm{Na}_{2} \mathrm{O} \cdot 7 \mathrm{SiO}_{2}$ ガラスで は $\mathrm{Fe}^{2+}$ イオンと $\mathrm{Cr}^{6+}$ イオンは共存しておらず, $\mathrm{Fe}^{2+}$ イオン又は $\mathrm{Cr}^{6+}$ イオンのいずれかが検出されたと報告 している. これは $\mathrm{Cr}^{6+}+3 \mathrm{Fe}^{2+} \rightleftharpoons \mathrm{Cr}^{3+}+3 \mathrm{Fe}^{8+}$ の反応 は右方向に偏っていることを意味している. 本実験にお けるこの反応の平衡定数は $950^{\circ} \mathrm{C}$ で $2.1 \times 10^{5}$ であり， 平衡はほとんど右方向に偏っており，Paul らの傾向と 一致している.

(2) $\mathrm{Mn}-\mathrm{As}$ 系: Paul ら は $\mathrm{Na}_{2} \mathrm{O} \cdot 4 \mathrm{~B}_{2} \mathrm{O}_{3}, 1000^{\circ} \mathrm{C}$ で平衡関係を調べ，七素イオンを含まない場合の $\mathrm{Mn}^{3+}$ $\mathrm{Mn}^{2+}$ の平衡值が 0.11 であったものが， ヒ素イオンと の共存後は $\mathrm{Mn}^{3+} / \mathrm{Mn}^{2+}=0.02$ に減少したと報告してい る. これは $2 \mathrm{Mn}^{8+}+\mathrm{As}^{3+} \rightleftharpoons 2 \mathrm{Mn}^{2+}+\mathrm{As}^{5+}$ は右に偏っ ていることを意味しており，本実験における傾向と一致 している.

(3) $\mathrm{Cr}-\mathrm{As}$ 系: Paul らは $3 \mathrm{Na}_{2} \mathrm{O} \cdot 7 \mathrm{SiO}_{2}, 1400^{\circ} \mathrm{C}$ で $2 \mathrm{Cr}^{6+}+3 \mathrm{As}^{3+} \rightleftharpoons 2 \mathrm{Cr}^{8+}+3 \mathrm{As}^{5+}$ の平衡定数として $1.1 \times 10^{4} \sim 10.7 \times 10^{4}$ を得ている. 本実験の $28.7 \mathrm{Na}_{2} \mathrm{O}$. $71.3 \mathrm{~B}_{2} \mathrm{O}_{3}, 950^{\circ} \mathrm{C}$ での平衡定数は $2.8 \times 10^{6}$ であり, ガ ラスの組成は異なるが，反応は大きく右偏している.

(4) $\mathrm{Mn}-\mathrm{Ce}$ 系: Paul ら $3 \mathrm{Na}_{2} \mathrm{O} \cdot 7 \mathrm{~B}_{2} \mathrm{O}_{3}$ 及び $\mathrm{Na}_{2} \mathrm{O} \cdot 4 \mathrm{~B}_{2} \mathrm{O}_{3}$ での $\mathrm{Mn}^{3+}+\mathrm{Ce}^{8+} \rightleftharpoons \mathrm{Mn}^{2+}+\mathrm{Ce}^{4+}$ の平衡 を調べた. 例えば $3 \mathrm{Na}_{2} \mathrm{O} \cdot 7 \mathrm{~B}_{2} \mathrm{O}_{3}, 1000^{\circ} \mathrm{C}$ で平衡定数 として 2.05〜2.13 という小さな值を得ている. 本実験 での值も 1 よりわずかに大きい程度であり, 反応は右偏 傾向にあるものの, 4 種のイオンが共存し得る系であ り, Paul らの結果と大略一致しているといえる. 
(5) $\mathrm{Cr}-\mathrm{Ce}$ 系: $\mathrm{Kühl}$ らの表 4 (a) では, $\mathrm{Cr}^{6+}$ イ オンは $\mathrm{Ce}^{3+}$ イオンを酸化する. しかし, Paul らはア ルカリケイ酸塩とアルカリホウ酸塩では逆の平衡関係を 得ている. まず $3 \mathrm{Na}_{2} \mathrm{O} \cdot 7 \mathrm{SiO}_{2}$ 中, $1400^{\circ} \mathrm{C}$ において, $\mathrm{Cr}^{6+}+3 \mathrm{Ce}^{3+} \rightleftharpoons \mathrm{Cr}^{3+}+3 \mathrm{Ce}^{4+}$ の平衡定数として $2.7 \times$ $10^{2} \sim 9.1 \times 10^{2}$ を得ている. 一方, $\mathrm{Na}_{2} \mathrm{O} \cdot 4 \mathrm{~B}_{2} \mathrm{O}_{3}$ 中, $1000^{\circ} \mathrm{C}$ で平衡定数として, $1.4 \times 10^{-4} \sim 9.1 \times 10^{-5}$ を得, 上記反応が左方すなわちセリウムが酸化㓮として作用す る方向に進行するといら結果定得ている. 本研究では, 平衡定数として, $950^{\circ} \mathrm{C} て ゙ ~ 4.9$ とわずかながら反応は右 方向に偏っているとの結果を得た. これは Paul らの結 果と全く逆である. この不一致の原因については今後更 に検討を加える必要があるが，Paul らの結果は急冷試 料についての值であり, 冷却中に存在比率が変化する可 能性も否定できない。

以上，本研究で得られた電気化学列及びそれに基づい て算出された平衡定数について, 従来の研究結果との主 として定性的な比較を試みた. 酸化還元平衡に関する定 量的知見を得る最良の方法は, 本研究のごとく“in situ” の状態でイオンの標準電位を決定し, 種々のレドックス 対の平衡定数を算出する方法であると考えられるが，工 業的応用を考えるに当たっては, 実用組成のガラス系を 含む種々のガラス融液について 測定を行う必要があろ う.

\section{6. 総 括}

アルカリホウ酸塩ガラスの一例として $28.7 \mathrm{Na}_{2} \mathrm{O}$ $71.3 \mathrm{~B}_{2} \mathrm{O}_{3}$ 融液における, $\mathrm{Cd}, \mathrm{Ni}, \mathrm{Zn}$ など単一原子価 イオン及び $\mathrm{Fe}, \mathrm{Cr}, \mathrm{As}$ などレドックスイオンの白金電 極における電極反応を三角波掃引ポテンシャルスイープ 法で調べた。種々の電位走査速度のもとで電流一電位曲 線の測定を行い，電極反応を決定した. $\mathrm{Cd}^{2+}, \mathrm{Zn}^{2+}$ 及 び低温度での $\mathrm{Ni}^{2+}$ イオンは可逆的 2 電子還元反応を受 け，金属状態まで還元されるが白金電極には析出しな い. 一方, $\mathrm{Pb}^{2+}$ 及び $\mathrm{Tl}^{+}$は電位走査速度が小さい範囲 で可逆的に還元を受け，白金電極上に析出した. この現 象はこれらの金属が水溶液中で白金上にファラデー吸着 しやすいことに対応している.レドックスイオンのう ち, $\mathrm{Fe}, \mathrm{Cu}, \mathrm{Sb}$ 及び $\mathrm{As}$ イオンは二つの還元ピークを 持ち, 高価数のイオン状態から段階的に還元を受けるこ とが分った. $\mathrm{Cr}, \mathrm{Ce}$ 及び $\mathrm{Mn}$ イオンも段階的に還元を 受けるはずであるが, 一つのピークのみが観察された.

第 2 ピークは負電位側に位置しているため残余電流の妨 害で観察されないものと考えた. Sn イオンの還元波に は反応生成物の吸着による前置ピークが観察された。ま た，低電位走查速度で主ピークは分裂した. クロノポテ
ンショメトリーで得た結果との比較より，多くのイオン について両手法の互換性が見いだされるとともに，ポテ ンシャルスイープ法では電極反応機構を更に詳しく調べ ることができることが分った.

電極反応が 可逆なものについては半波電位を求め, $950^{\circ}, 900^{\circ}, 850^{\circ}$ 及び $790^{\circ} \mathrm{C}$ における電気化学列を作成 した. これを Kühl らの内部酸素圧による酸化力の評 価法と比較した場合, $\mathrm{Cr}, \mathrm{Mn}$ 及び $\mathrm{Ce}$ イオンの間での 酸化力は, ともに $\mathrm{Cr}^{6+} / \mathrm{Cr}^{3+}>\mathrm{Mn}^{3+} / \mathrm{Mn}^{2+}>\mathrm{Ce}^{4+} / \mathrm{Ce}^{3+}$ の順であったが，As． $\mathrm{Sb}$ イオンの順位には逆転が見 られた. 電気化学列では, 酸化力は $\mathrm{Sb}^{5+} / \mathrm{Sb}^{3+}>\mathrm{As}^{5+} /$ $\mathrm{As}^{3+}$ の順であり, Baak らのこれらの系の自由エネル ギーの密閉系における測定結果を支持した.

次に, 種々のイオンの電極電位より任意の 2 種のレド ックス対間の反応の平衡定数を算出した. $\mathrm{Fe}-\mathrm{Ce}$ 系の平 衡定数は急冷試料の化学分析による值と大略一致した. また, Paul らの分光学的手法によるケイ酸塩及びホウ 酸塩ガラスに拉けるレドックス対間の反応の研究結果と の比較では, $\mathrm{Cr}-\mathrm{Fe}, \mathrm{Mn}-\mathrm{As}$ 及び $\mathrm{Cr}-\mathrm{As}$ 系については 反応の進行方向は一致した. $\mathrm{Mn}-\mathrm{Ce}$ 系については平衡 定数は大略一致したが, $\mathrm{Cr}-\mathrm{Ce}$ 系では逆の傾向となり， 再検討の必要性が認められた.

謝 辞 本研究の実施に当たって測定実験に協力された古 林行雄, 柳俊徳の各氏に深謝する.

\section{文献}

1）三浦嘉也，高橋克明，窯協，87，189-97 (1979).

2) P. Delahay, "New Instrumental Methods in Electrochemistry" Interscience Pub., N.Y. (1954) p. 115-45.

3) T. Matsuda and Y. Ayabe, Z. Electrochem., 59, 494502 (1955).

4）高橋克明, 三浦嘉也, 窯協, 87, 94-105 (1979).

5) R.H. Wopschall and I. Schain, Anal. Chem., 39, 1514-27 (1967).

6) S. Banerjee and A. Paul, J. Am. Ceram. Soc., 57, 286-90 (1974).

7) H.H. Bauer, "Electrodics", G. Thieme Verlag (1972); 玉虫伶太・佐藤弦訳,「電極反応」, 東京化学同人(1976) p. 13-32.

8）三国房子，高村 勉，電気化学，37，852-56 (1969) ; ibid., 38, 113-18 (1970).

9) A. Paul and D. Lahiri, J. Am. Ceram. Soc., 49, 565-68 (1966).

10) C. Kühl, H. Rudow and W.A. Weyl, Sprechsaal, 71, 91-3, 104-06, 117-18 (1938).

11) H.J. Tress, Phys. Chem. Glasses, 1, 196-97 (1960).

12) T. Baak and E.J. Hornyak, Glass Ind., 374-77, 41858 (1966).

13) A. Paul and R. W. Douglas, Phys. Chem. Glasses, 7, 1-13 (1966). 